\title{
The crystal structure of Ga-rich plumbogummite from Tsumeb, Namibia
}

\author{
S. J. Mills ${ }^{1, *}$, A. R. KAMPF ${ }^{2}$, M. Raudsepp ${ }^{1}$ AND A. G. Christy ${ }^{3}$ \\ ${ }^{1}$ Department of Earth and Ocean Sciences, University of British Columbia, Vancouver, British Columbia V6T 1Z4, \\ Canada \\ ${ }^{2}$ Mineral Sciences Department, Natural History Museum of Los Angeles County, 900 Exposition Boulevard, Los \\ Angeles, California 90007, USA \\ ${ }^{3}$ Research School of Earth Sciences, The Australian National University, Canberra ACT 0200, Australia
}

[Received 23 April 2009; Accepted 1 September 2009]

\section{ABSTRACT}

Ga-rich plumbogummite, $\left(\mathrm{Pb}_{0.87}, \mathrm{Ca}_{0.13}\right)_{\Sigma 1.00} \mathrm{H}\left(\mathrm{Al}_{1.95}, \mathrm{Ga}_{1.05}\right)_{\Sigma 3.00}\left(\mathrm{PO}_{4}\right)_{2}(\mathrm{OH})_{6}$, from Tsumeb, Namibia, has rhombohedral symmetry, space group $R \overline{3} \mathrm{~m}$, with the cell parameters $a=7.0752(19) \AA, c=$ $16.818(4) \AA$ and $V=729.1(3) \AA^{3}$. The crystal structure has been refined to $R_{1}=2.05 \%$. Ga-rich plumbogummite has an alunite-type structure comprised of a rhombohedral stacking of (001) composite layers of corner-shared $(\mathrm{Al}, \mathrm{Ga}) \mathrm{O}_{6}$ octahedra and $\mathrm{PO}_{4}$ tetrahedra, with $\mathrm{Pb}$ atoms occupying icosahedrally coordinated sites between the layers. The $\mathrm{Pb}$ and $\mathrm{H}$ positions are discussed. Ga-rich plumbogummite is nonpleochroic, uniaxial $(+)$, with indices of refraction, $\varepsilon=1.742(3)$ and $\omega=1.722(3)$, determined in white light. The five strongest powder-diffraction lines $\left[d\right.$ in $\AA$, $\left.\left(I / I_{\mathrm{o}}\right),(h k l)\right]$ are: $2.995,(100),(113)$; 5.766, (95), (101); 2.236, (43), (107, 122); 3.539, (38), (110); 1.919 (32), (303, 033).

KeYwords: plumbogummite, Tsumeb, Namibia, gallium, crystal structure, kintoreite, bond valence.

\section{Introduction}

Members of the alunite supergroup have the general formula $A B_{3}\left(T \mathrm{O}_{4}\right)_{2}\left(\mathrm{OH}, \mathrm{H}_{2} \mathrm{O}\right)_{6}$, where $A$ is a large cation site containing cations such as $\mathrm{Na}^{+}, \mathrm{K}^{+}, \mathrm{H}_{3} \mathrm{O}^{+}, \mathrm{Ba}^{2+}, \mathrm{Sr}^{2+}, \mathrm{Ca}^{2+}, \mathrm{Pb}^{2+}$ and $R E E^{3+}$. The $B$ site is octahedrally coordinated, containing typically $\mathrm{Al}^{3+}$ or $\mathrm{Fe}^{3+}$, but it can also include $\mathrm{V}^{3+}$, $\mathrm{Ga}^{3+}, \mathrm{Zn}^{2+}$ and $\mathrm{Cu}^{2+}$. The $T$ site is tetrahedrally coordinated and is occupied by S, P or As (Scott, 1987; Jambor, 1999). Most alunite-related minerals have rhombohedral symmetry, $R \overline{3} m$, with hexagonal cell parameters $a_{\mathrm{h}} \approx 7 \AA, c_{\mathrm{h}} \approx 17 \AA$ (e.g. crandallite, $\left(\mathrm{CaAl}_{3}\left(\mathrm{PO}_{3}\left[\mathrm{O}_{0.5} \mathrm{OH}_{0.5}\right]\right)_{2}(\mathrm{OH})_{6}-\right.$ Blount, 1974). The composition often varies due

* E-mail: smills@eos.ubc.ca

DOI: 10.1180/minmag.2009.073.5.837 to solid-solution series encompassing all cation sites. Such modifications include $\mathrm{OH}$ substitution for oxygen in the $T \mathrm{O}_{4}$ tetrahedra, substitution of $\mathrm{H}_{2} \mathrm{O}$ or oxygen for $\mathrm{OH}$, and partial occupancy of the $A$ and/or $B$ sites (Jambor, 1999).

At the Tsumeb mine, in the Otjikoto region of Namibia $\left(19^{\circ} 15^{\prime} \mathrm{S}, 17^{\circ} 42^{\prime} \mathrm{E}\right), \mathrm{Ga}$ is known as an essential constituent in several Pb-bearing members of the alunite supergroup. These minerals include: gallobeudantite, $\mathrm{PbGa}_{3}$ $\left[\left(\mathrm{AsO}_{4}\right),\left(\mathrm{SO}_{4}\right)\right]_{2}(\mathrm{OH})_{6}$ (Jambor et al., 1996) and several unnamed $\mathrm{Ga}$ analogues of $\mathrm{Pb}$-bearing species of the supergroup. The Tsumeb mine is the type locality for approximately 58 other minerals. An overview of the mineralogy of the Tsumeb deposit can be found in Gebhard (1999). Here, we report the results of two crystal-structure refinements of Ga-rich plumbogummite from Tsumeb, Namibia. This is also the first report of plumbogummite from Tsumeb. 


\section{Experimental}

\section{Sample}

Ga-rich plumbogummite occurs with the unnamed $\mathrm{Ga}$ analogue of arsenocrandallite and an unnamed $\mathrm{Zn}-\mathrm{Fe}-\mathrm{Ga}$ oxide (under investigation) in a $20 \mathrm{~mm} \times 10 \mathrm{~mm} \times 10 \mathrm{~mm}$ piece of galliterenierite-germanite ore. A similar assemblage (and host rock) was described by Jambor et al. (1996), which included the Ga analogues of several Pb-bearing species of the alunite supergroup (gallobeudantite and the unnamed $\mathrm{Ga}$ analogues of kintoreite, arsenocrandallite, segnitite and corkite) as zoned crystals. The paragenesis of the Ga-rich plumbogummite specimen differs from that of type gallobeudantite, with only the unnamed Ga analogue of arsenocrandallite (IMA Code: UM1996-04-AsO:CaGaGeH; Smith and Nickel, 2007) being observed. The sample has been deposited in the collections of Mineral Sciences Department, Natural History Museum of Los Angeles County, catalogue number 62425.

Gallium-rich plumbogummite occurs as white, transparent, rhombohedral single crystals up to
$300 \mu \mathrm{m}$ across, which sit perched on the galliterenierite-germanite ore. Ga-rich plumbogummite rarely forms as intergrown crystals, which may be up to $0.5 \mathrm{~mm}$ across. Its streak is white, it has a vitreous lustre; forms are dominated by the rhombohedron $\{112\}$ and it is visually indistinguishable from the unnamed $\mathrm{Ga}$ analogue of arsenocrandallite.

\section{Structure refinement}

The single-crystal study was done using a Bruker X8 ApexII single-crystal diffractometer at the Department of Chemistry, University of British Columbia. A rhombohedral crystal with the dimensions $0.3 \mathrm{~mm} \times 0.2 \mathrm{~mm} \times 0.1 \mathrm{~mm}$ was used for collection of intensity data at $293 \mathrm{~K}$ (Table 1). A second crystal structure refinement was completed on another crystal. A summary of these results are listed in an Appendix.

The intensity data were processed with the Bruker Apex program suite, with data reduction using the SAINT program (Bruker, 2005) and absorption correction by the multi-scan method

TABle 1. Summary of data collection conditions and refinement parameters for Ga-rich plumbogummite.

Crystal data

Cell parameters

Space group

Data collection

Temperature $(\mathrm{K})$

$\lambda($ Mo- $K \alpha) \AA$

Crystal shape, size $(\mathrm{mm})$

$2 \theta \max \left({ }^{\circ}\right)$

Reflection range

Total no. reflections

No. unique reflections

No. reflections, $F_{\mathrm{o}}>4 \sigma(F)$

Absorption correction

$R_{\text {merg }}$ on $F^{2}$

Refinement

No. parameters refined

$R_{1}, F_{\mathrm{o}}>4 \sigma(F)$

$R_{1}$, all data

$w R_{2}\left(F^{2}\right)^{*}$, all data

Goodness of Fit

$\Delta \sigma_{\min }, \Delta \sigma_{\max }\left(\mathrm{e} / \AA^{3}\right)$

$$
\begin{aligned}
& a=7.0752(19) \AA \\
& c=16.818(4) \AA \\
& V=729.1(3) \AA^{3} \\
& Z=3 \\
& R \overline{3} m
\end{aligned}
$$

293(2)

0.71073

rhombohedron, $0.03 \times 0.03 \times 0.02$

59.98

$-6 \leqslant h \leqslant 9 ;-9 \leqslant k \leqslant 9 ;-22 \leqslant l \leqslant 21$

1846

271

267

$\mu=26.04 \mathrm{~mm}^{-1}$

0.0287

39

0.0205

0.021

0.0437

1.339

$-0.48,0.43$

$* w=1 /\left[\sigma^{2}\left(F_{\mathrm{o}}^{2}\right)+\left(0.0075 \mathrm{P}^{2}+5.64 \mathrm{P}\right)\right], \mathrm{P}=\left[2 F_{\mathrm{c}}^{2}+\operatorname{Max}\left(F_{\mathrm{o}}^{2}, 0\right)\right] / 3$. 
using SADABS (Bruker, 2005). Minor splitting of the spots was observed, indicating the presence of two twin individuals. However, the spots could be integrated with a single spot size and preceded normally to convergence. Twinning is a common phenomenon in alunite supergroup minerals (e.g. kintoreite - Kharisun et al., 1997a; segnitite Birch et al., 1992), whereas twin sector zoning is less common (e.g. alunite - Bajnóczi et al., 2004).

The crystal structure of Ga-rich plumbogummite was refined in space group $R \overline{3} m$ (No. 166), using SHELXL-97 (Sheldrick, 2008) with the starting coordinates of Kolitsch et al. (1999a). In the Kolitsch et al. model, the $\mathrm{Pb}$ atom is at the $18 f$ site $[x, x, z]$, whereas in kintoreite, the $\mathrm{Fe}^{3+}$ analogue of plumbogummite, the $\mathrm{Pb}$ atom has been reported at the $36 i$ general position (Kharisun et al., 1997a) and the $18 f$ position $[x, 0,0]$ by Grey et al. (2009). As reported for kintoreite (Grey et al., 2009), there is little difference in the $R$ factor of Ga-rich plumbogummite when $\mathrm{Pb}$ is assigned to any of the sites $[x, x, z],[x, ; 0,0]$ and the $18 h$ site $[x,-x, z]$ (where $z \sim 0$ ), as all three sites describe adequately the statistical distribution of $\mathrm{Pb}$ about the (001) plane. We note that in the structure of Ga-rich plumbogummite, refinement of $\mathrm{Pb}$ at the origin $(0,0,0)$ dramatically increased the $R$ factor, indicating that the $\mathrm{Pb}$ atom is displaced off the origin. Giuseppetti and Tadini $(1980,1987)$ reported the $\mathrm{Pb}$ atom on the origin in the structures of osarizawaite and corkite; however, the $\mathrm{Pb}$ atom had large thermal ellipsoids, which indicate stereochemical activity of the $6 s^{2}$ lone pair. Here, we report off-centring to the $[x, 0,0]$ position for the $\mathrm{Pb}$, consistent with other refinements.

The final model for the refinement converged to $R_{1}=2.05 \%$ for 267 reflections $\left[F_{\mathrm{o}}>4 \sigma\left(F_{\mathrm{o}}\right)\right]$, and 2.10 for all 271 reflections. The refined atom coordinates, site occupancies and displacement parameters are given in Table 2; bond distances in Table 3, and a bond-valence analysis in Table 4.

\section{X-ray powder diffraction}

Powder data were obtained using a Rigaku R-AXIS SPIDER large-area curved-imagingplate microdiffractometer with monochromatized Mo- $K \alpha(\lambda=0.71075 \AA)$ radiation on the same crystal used for single-crystal structure refinement. Unit-cell data (parameters refined from the powder data using Chekcell - Laugier and Bochu, 2004) are given in Table 5.

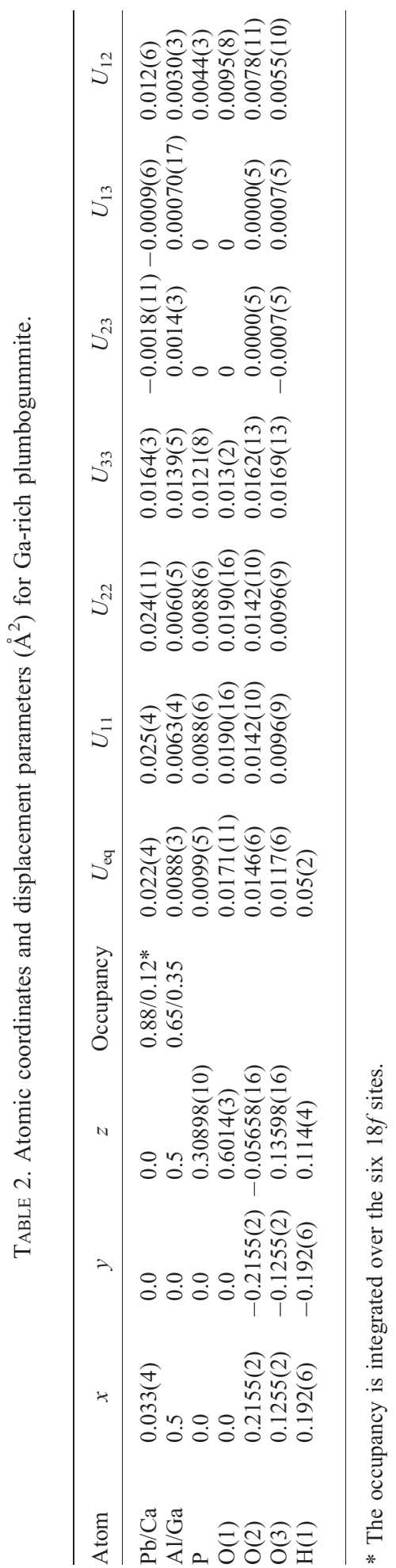


Table 3. Polyhedral bond distances $(\AA)$ in Ga-rich plumbogummite.

\begin{tabular}{lll}
\hline$(\mathrm{Al} / \mathrm{Ga})-\mathrm{O}(2)$ & $1.947(1)$ & $\times 2$ \\
$(\mathrm{Al} / \mathrm{Ga})-\mathrm{O}(3)$ & $1.914(1)$ & $\times 4$ \\
$<(\mathrm{Al} / \mathrm{Ga})-\mathrm{O}>$ & 1.925 & \\
$\mathrm{P}-\mathrm{O}(1)$ & $1.507(5)$ & \\
$\mathrm{P}-\mathrm{O}(2)$ & $1.542(3)$ & $\times 3$ \\
$<\mathrm{P}-\mathrm{O}>$ & 1.533 & \\
& & \\
$(\mathrm{~Pb} / \mathrm{Ca})-\mathrm{O}(2)$ & 2.614 & $\times 2$ \\
$(\mathrm{~Pb} / \mathrm{Ca})-\mathrm{O}(2)$ & 2.817 & $\times 2$ \\
$(\mathrm{~Pb} / \mathrm{Ca})-\mathrm{O}(2)$ & 3.007 & $\times 2$ \\
$(\mathrm{~Pb} / \mathrm{Ca})-\mathrm{O}(3)$ & 2.647 & $\times 2$ \\
$(\mathrm{~Pb} / \mathrm{Ca})-\mathrm{O}(3)$ & 2.766 & $\times 2$ \\
$(\mathrm{~Pb} / \mathrm{Ca})-\mathrm{O}(3)$ & 2.880 & $\times 2$ \\
$<\mathrm{Pb} / \mathrm{Ca}>-\mathrm{O}(3)$ & 2.789 & \\
& & \\
& &
\end{tabular}

\section{Optical characterization}

The crystal used for the structure determination was also used for optical characterization. The crystal showed some layering and possible sector zoning or twinning in parts, confirming the twinning observations noted above; however the majority of the crystal was homogeneous. The crystal was split up into fragments, where the individuals showed the following characteristics: nonpleochroic, uniaxial $(+)$, with indices of refraction, $\varepsilon=1.742(3)$ and $\omega=1.722(3)$ determined in white light. The crystal showed some bluish colours prior to splitting; this seems to be an interference effect related to the growth layers as opposed to actual bluish interference colours observed for some alunite-supergroup members (e.g. dussertite - Kolitsch et al., 1999b).
Ga-rich plumbogummite shows higher refractive indices than the typical range for plumbogummite: $\omega=1.653-1.688$ and $\varepsilon=1.675-1.704$ (Anthony et al., 2000) in accord with the high Ga content. Plumbogummite has also been noted as being biaxial $(+)$ with a small $2 \mathrm{~V}$ value (e.g. Hintze, 1933; Slansky, 1977); however, this was not observed in the Ga-rich plumbogummite crystals. Recently, however, several biaxial species - pattersonite, a dimorph of kintoreite, $\mathrm{PbFe}_{3}\left(\mathrm{PO}_{4}\right)_{2}(\mathrm{OH})_{4}\left[\left(\mathrm{H}_{2} \mathrm{O}\right)_{0.5}(\mathrm{OH})_{0.5}\right]_{2}$ (Kolitsch et al., 2008) and kolitschite, $\mathrm{PbZn}_{0.5} \mathrm{Fe}_{3}$ $\left(\mathrm{AsO}_{4}\right)_{2}(\mathrm{OH})_{6}$, related to segnitite (Grey et al., 2008; Mills et al., 2008) - have been shown to be new minerals related to the alunite supergroup members. These new discoveries shed light on the complex crystal chemistry of the alunite supergroup. A re-examination of some of these previously described plumbogummites, such as those described by Hintze (1933) and Slansky (1977), seems highly desirable.

\section{Discussion}

\section{Crystal structure}

The crystal structure of plumbogummite (Kolitsch et al., 1999a), is a typical rhombohedral alunitetype structure (e.g. Blount, 1974) made up of (001) sheets of corner-shared $\mathrm{Al}$ octahedra and $\mathrm{P}$ tetrahedra that stack along $c$ (Fig. 1). The $\mathrm{Pb}$ atoms occupy icosahedrally coordinated sites between the layers. The stacking of two composite octahedral/tetrahedral layers, with interlayer $\mathrm{Pb}$ atoms, is shown in Fig. 2. The octahedra share corners via hydroxyl anions, $\mathrm{O}(3)$, to form a planar network of triangular clusters encompassing hexagonal voids. Such networks are often described as hexagonal tungsten bronze (HTB) layers (e.g. Grey et al., 2006). The apical oxygen

TABLE 4. Bond-valence analysis for Ga-rich plumbogummite.

\begin{tabular}{|c|c|c|c|c|c|c|c|c|c|c|}
\hline & $\mathrm{Pb} / \mathrm{Ca}^{\mathrm{KB}}$ & $\mathrm{Pb} / \mathrm{Ca}^{\mathrm{BO}}$ & & $\mathrm{Al} / \mathrm{Ga}$ & & $\mathrm{P}$ & & $\mathrm{H}(1)$ & Total $^{\mathrm{KB}}$ & Total $^{\mathrm{BO}}$ \\
\hline $\mathrm{O}(1)$ & & & & & & 1.34 & & 0.27 & 1.61 & 1.61 \\
\hline $\mathrm{O}(2)$ & 0.18 & 0.16 & $\downarrow \times 6$ & 0.47 & $\downarrow \times 2$ & 1.22 & $\downarrow \times 3$ & & 2.26 & 2.20 \\
\hline $\mathrm{O}(3)$ & $\begin{array}{l}0.19 \\
2.19\end{array}$ & $\begin{array}{l}0.17 \\
1.97\end{array}$ & $\downarrow \times 6$ & $\begin{array}{l}0.50 \\
2.94\end{array}$ & $\downarrow \times 4$ & 5.00 & & $\begin{array}{l}0.73 \\
1.00\end{array}$ & 1.92 & 1.86 \\
\hline
\end{tabular}

$\mathrm{KB}=$ Using the $\mathrm{Pb}-\mathrm{O}$ parameters of Krivovichev and Brown (2001).

$\mathrm{BO}=$ Using the $\mathrm{Pb}-\mathrm{O}$ parameters of Breese and O'Keeffe (1991). 
TABle 5. X-ray powder diffraction data for Ga-rich plumbogummite.

\begin{tabular}{|c|c|c|c|c|c|c|}
\hline$I_{\text {obs. }}$ & $d_{\text {obs. }}$ & $d_{\text {calc. }}$ & $I_{\text {calc. }}{ }^{*}$ & $h$ & $k$ & $l$ \\
\hline 95 & 5.766 & 5.76 & 100 & 1 & $\mathbf{0}$ & 1 \\
\hline 7 & 4.96 & 4.955 & 6 & 0 & 1 & 2 \\
\hline 38 & 3.539 & 3.539 & 36 & 1 & 1 & 0 \\
\hline 11 & 3.46 & 3.47 & 11 & 1 & 0 & 4 \\
\hline 100 & 2.995 & 2.994 & 97 & 1 & 1 & 3 \\
\hline 17 & 2.886 & 2.88 & 28 & 2 & 0 & 2 \\
\hline 11 & 2.807 & 2.806 & 15 & 0 & 0 & 6 \\
\hline 19 & 2.479 & 2.478 & 19 & 0 & 2 & 4 \\
\hline 13 & 2.296 & 2.295 & 13 & 2 & 1 & 1 \\
\hline & & 2.239 & 31 & 1 & 0 & 7 \\
\hline 43 & 2.236 & 2.235 & 16 & 1 & 2 & 2 \\
\hline 9 & 2.199 & 2.199 & 9 & 1 & 1 & 6 \\
\hline 6 & 2.029 & 2.03 & 7 & 2 & 1 & 4 \\
\hline & & 1.92 & 5 & 3 & $\mathbf{0}$ & 3 \\
\hline 32 & 1.919 & 1.92 & 23 & 0 & 3 & 3 \\
\hline 23 & 1.769 & 1.77 & 20 & 2 & 2 & 0 \\
\hline 5 & 1.737 & 1.735 & 6 & 2 & 0 & 8 \\
\hline 8 & 1.665 & 1.667 & $<1$ & 3 & 1 & 2 \\
\hline & 1.000 & 1.667 & 6 & 2 & 1 & 7 \\
\hline 10 & 1.654 & 1.654 & 8 & 1 & 1 & 9 \\
\hline 8 & 1.518 & $\begin{array}{l}1.518 \\
1.517\end{array}$ & $\begin{array}{l}6 \\
5\end{array}$ & 3 & 1 & $\begin{array}{l}5 \\
2\end{array}$ \\
\hline 16 & 1.498 & 1.497 & 12 & 2 & 2 & 6 \\
\hline 12 & 1.474 & 1.476 & 14 & 0 & 2 & 10 \\
\hline 5 & 1.442 & 1.44 & 4 & 4 & 0 & 4 \\
\hline 4 & 1.4 & 1.402 & 3 & 3 & 2 & 1 \\
\hline 6 & 1.388 & 1.388 & 5 & 1 & 3 & 7 \\
\hline & & 1.38 & 1 & 3 & 0 & 9 \\
\hline 5 & 1.381 & 1.38 & 4 & 0 & 3 & 9 \\
\hline & & 1.301 & 5 & 4 & 1 & 3 \\
\hline 11 & 1.301 & 1.301 & 3 & 1 & 4 & 3 \\
\hline
\end{tabular}

* Using the crystal structure data with $a=7.0752 \AA, c=$ $16.8183 \AA$.

anions, $\mathrm{O}(2)$, of the triangular groupings of octahedra are shared with the $\mathrm{PO}_{4}$ tetrahedra.

The $\mathrm{TO}_{4}$ tetrahedron in the alunite structuretype has one short apical $T-\mathrm{O}(1)$ distance and three longer $T-\mathrm{O}(2)$ distances. In Ga-rich plumbogummite, these distances are 1.507 and $1.541 \AA$ respectively, giving a $<\mathrm{P}-\mathrm{O}>$ of $1.533 \AA$. The average bond length matches well with the value of $1.537 \AA$ reported by Huminicki and Hawthorne (2002) for phosphate minerals and $1.56 \AA$ reported by Kolitsch et al. (1999a) for plumbogummite with 5\% As. Approximately $2-3 \% \mathrm{~S}$ might be substituting at the site; however, refinements were unable to determine this unambiguously.

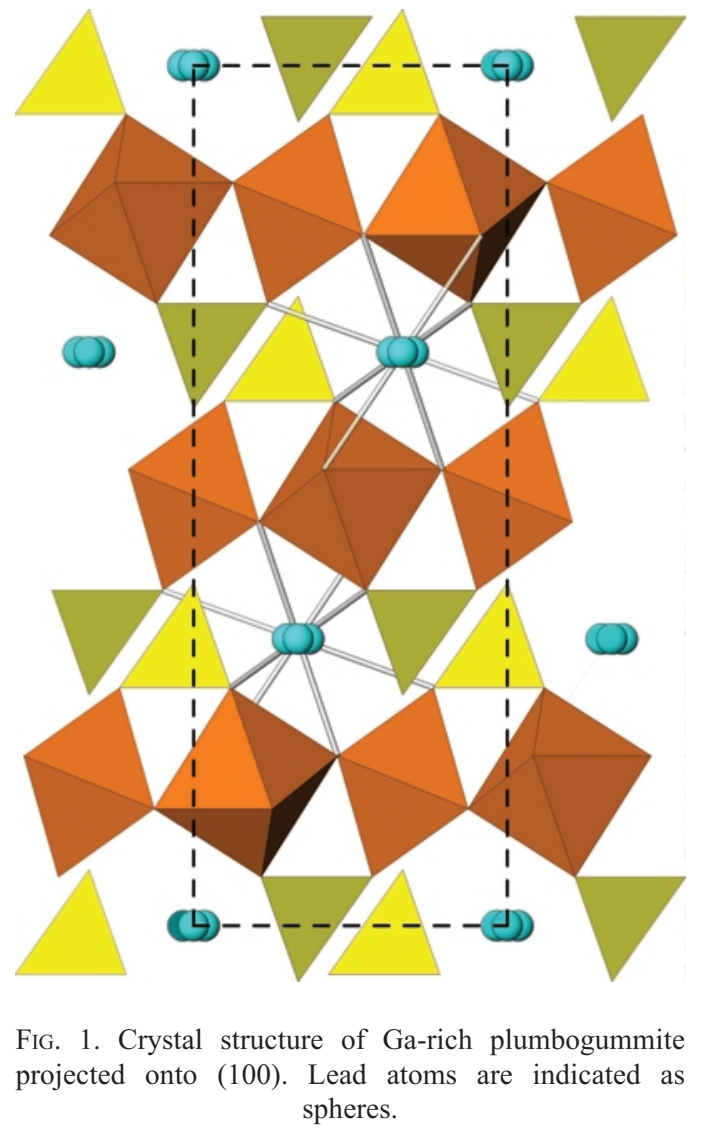

The $\mathrm{BO}_{6}$ octahedron in the alunite structuretype has two long $B-\mathrm{O}(2)$ distances and four short $B-\mathrm{O}(3)$ distances. In Ga-rich plumbogummite, these distances are 1.947 and $1.914 \AA$ respectively, giving an $<\mathrm{Al} / \mathrm{Ga}-\mathrm{O}>$ of $1.925 \AA$, and a refined site occupancy of $\mathrm{Al}_{0.66} \mathrm{Ga}_{0.34}$.

The large $A$ cation site in the alunite-type structure is in 12-coordination. In the ideal case, the cation is located at the origin and has symmetrical coordination with bonds of equal length to six $O(2)$ and to six $O(3)$ atoms. However, as described above, in the majority of $\mathrm{Pb}$ members of the alunite supergroup, the $\mathrm{Pb}$ coordination environment is displaced and distorted, and the $\mathrm{Pb}$ atom exhibits stereochemical activity of the $6 s^{2}$ lone-pair electrons (Mills, 2007). The stereochemical activity of the $\mathrm{Pb} 6 s^{2}$ lone-pair electrons has been described in a number of minerals and compounds (e.g. joesmithite - Moore, 1988; wherryite - Cooper and Hawthorne, 1994; mawbyite - Kharisun et al., 1997b; synthetic $\mathrm{Pb}_{4} \mathrm{BiO}_{4} \mathrm{PO}_{4}-$ Giraud et al. 


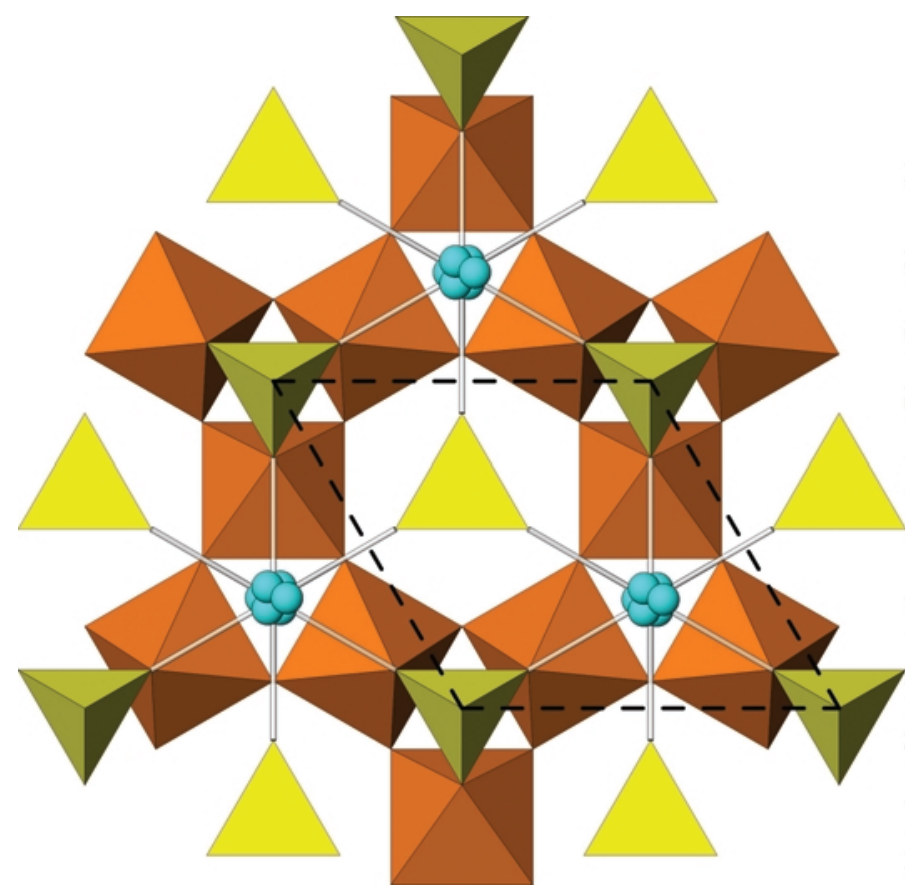

FIG. 2. Crystal structure of Ga-rich plumbogummite projected onto (001). Lead atoms are indicated as spheres.

1999). In Ga-rich plumbogummite, the $A$ cation is located at a $(x, 0,0)$ site and is displaced from the origin by $0.242 \AA$. The $A$ cation has two short $(2.614 \AA)$, two medium $(2.817 \AA)$ and two long bonds ( $3.007 \AA$ ) to $\mathrm{O}(2)$, whereas to $\mathrm{O}(3)$, the two short bonds are $2.647 \AA$, and there are two pairs of medium length bonds of 2.766 and $2.880 \AA$. During refinement, the $R$-factor is substantially reduced by refining the occupancy, as $\mathrm{Ca}$ or $\mathrm{Ba}$ commonly occupies this site in $\mathrm{Pb}$-bearing members (Mills, 2007). In Ga-rich plumbogummite, the site refined to $\mathrm{Pb}_{0.88} \mathrm{Ca}_{0.12}$, indicating partial solid solution toward crandallite. The $<\mathrm{Pb} / \mathrm{Ca}-\mathrm{O}>$ distance of $2.789 \AA$ is in accord with literature values for alunite supergroup minerals. It is interesting to note that the $\mathrm{Pb}$ atom in the plumbogummite structure of Kolitsch et al. (1999a) refined to full occupancy, and it seems that the $\mathrm{Pb}$ in the gallobeudantite structure also has full occupancy (Jambor et al., 1996).

Two published sets of parameters can be used for the determination of the bond valence for the $A$ site. Recently, Krivovchev and Brown (2001) re-determined the bond valence parameters for $\mathrm{Pb}$ for structures where $\mathrm{Pb}$ is encapsulated by $\mathrm{O}^{2-}$ as $\mathrm{OPb}_{4}$. The result was a change in the parameters from $r_{0}=2.112 \AA$ and $b=0.37 \AA$ (Brese and O'Keeffe, 1991) to $r_{0}=1.963 \AA$ and $b=0.49 \AA$ for $\mathrm{Pb}-\mathrm{O}$ bonds. For Ga-rich plumbogummite, a bond valence sum (BVS) of 2.19 v.u. for the $A$ site is obtained using the parameters of Krivovichev and Brown (2001). In contrast, if the parameters of Brese and O'Keeffe (1991) are used, the valence sum is 1.97 v.u. Thus, the parameters of Krivovichev and Brown (2001) tend to overestimate the bonding to $\mathrm{Pb}$ in the $A$ site. Although $\mathrm{OM}_{4}$ bonds fit the general $r_{0}-b$ trend for $M \mathrm{O}_{\mathrm{n}}$ (in this case $M=\mathrm{Pb}$ ), they appear to, on average, overestimate the valence of the ion, which may reflect $M \ldots M$ repulsion in the $M_{4}$ tetrahedron. Recalculation of the BVS for the plumbogummite of Kolitsch et al. (1999a) shows the same overbonding features. Using the parameters of Brese and O'Keeffe, the fully occupied $\mathrm{Pb}$ site has a BVS of 2.11 v.u., whereas Krivovchev and Brown's parameters give a significantly larger sum of 2.35 v.u. In contrast, the $\mathrm{O}(2)$ oxygen bonded to $\mathrm{Pb}$ has a valence sum of 2.26 v.u. using the Krivovichev and Brown parameters or 2.20 using those of Brese and O'Keeffe (1991), so this atom is overbonded to a similar degree for either choice of parameters, implying that the para- 
meterization for the $\mathrm{Pb}-\mathrm{O}$ bonds is not the cause, but rather geometrical constraints on the maximum possible lengthening of the other cation $-\mathrm{O}(2)$ bonds.

In the alunite structure type, it is common to determine the $\mathrm{H}(1)$ atom position. It has generally been described on a $[x,-x, z]$ site where it forms as an $\mathrm{O}(3)-\mathrm{H}(1) \ldots \mathrm{O}(1)$ bond. In Ga-rich plumbogummite, it has a distance of $1.008 \AA$ and an $\mathrm{O}-\mathrm{O}$ distance of $2.81 \AA$, categorized as a weak hydrogen bond (Libowitzky and Beran, 2004). The contribution to the BVS is 0.73 v.u. to $\mathrm{O}(3)$ and 0.27 v.u. to $\mathrm{O}(1)$ which leaves both $\mathrm{O}$ atoms undersaturated (Table 4). It has often been speculated that a second hydrogen bond exists within the structure (e.g. Blount, 1974 in crandallite); however, this has yet to be confirmed. In Ga-rich plumbogummite, $\mathrm{O}(1)$ has a valence of 1.61 indicating that it is at least partially protonated. As $\mathrm{O}(2)$ is significantly overbonded, an inter- $\mathrm{PO}_{4}$ hydrogen bond of the type $\mathrm{O}(1)-\mathrm{H}(2) \cdots \mathrm{O}(2)$, as is proposed for kintoreite by Grey et al., (2009), is impossible. One more likely scenario involves an $\mathrm{O}(1)-\mathrm{H}(2) \ldots \mathrm{O}(1)$ hydrogen bond which is formed between the proton, $\mathrm{H}(2)$, and the $\mathrm{O}(1)$ atoms of opposing tetrahedra on either side of the hexagonal rings. This $\mathrm{O}(1)-\mathrm{O}(1)$ distance is considerably larger at $\sim 3.4 \AA$ than the distance noted for crandallite $(2.99 \AA)$ and kintoreite $(3.21 \AA)$. For this to occur, the $\mathrm{O}(1)-\mathrm{H}(2)$ distance would be expected to be very short (Nakamoto et al., 1955) and the $\mathrm{P}-\mathrm{O}(1)$ distance should be correspondingly elongated (Ferraris and Ivaldi, 1984). However, the $\mathrm{P}-\mathrm{O}(1)$ distance is much shorter $(1.509 \AA)$ than the three $\mathrm{P}-\mathrm{O}(2)$ distances of $1.544 \AA$.

\section{Formation conditions}

Mills (2007) was able to synthesize Ge- and Garich equivalents of segnitite, the As- and Feanalogue of plumbogummite. Here, under only a limited $\mathrm{pH}$ range $(1-1.5)$, crystals with the alunite structure type were produced. During that study (Mills, 2007), attempts to synthesize the $\mathrm{Ga}$ and $\mathrm{P}$ equivalent (between $\mathrm{pH} 1$ and 4 in a $\mathrm{Ga}$ saturated hydrothermal solution) were unsuccessful. In all cases, the P-analogue of schultenite precipitated and the $\mathrm{Ga}$ remained unreacted. In the presence of $\mathrm{Fe}$ and $\mathrm{Ge}$, the new compound $\mathrm{Pb}_{3} \mathrm{Fe}_{2}\left(\mathrm{PO}_{4}\right)_{4}\left(\mathrm{H}_{2} \mathrm{O}\right)$ was synthesized. This phase also has the potential to be discovered as a new mineral.
Considering that Ga-rich plumbogummite occurs on Ga-rich ore, it is somewhat surprising that only about one third of the $\mathrm{Al}$ is substituted by $\mathrm{Ga}$ considering the octahedral radii of $\mathrm{Al}$ is $0.535 \AA$ vs. $0.62 \AA$ for Ga. Ideally, it should be possible for a complete solid solution to exist between plumbogummite and the, as yet unidentified, Ga-analogue. It seems that more than abundant $\mathrm{Ga}$ is required for the Ga-dominant end-member $\left(\mathrm{PbGa}_{3} \mathrm{H}\left(\mathrm{AsO}_{4}\right)_{2}(\mathrm{OH})_{6}\right)$ to form $\mathrm{pH}$ and Eh conditions must therefore play a major role. We note that in gallobeudantite, substantial $\mathrm{Fe}^{3+}$ and $\mathrm{Al}$ substitution occurs for $\mathrm{Ga}$, and that a pure $\mathrm{Ga}$ end-member of that mineral is yet to be discovered.

\section{Acknowledgements}

The Principal Editor, Mark Welch, and Frank Hawthorne provided helpful comments on the manuscript which greatly improved its quality. NSERC Canada is thanked for a Discovery Grant to Mati Raudsepp. Mr John Dagenais of Vancouver, BC, Canada is thanked for bringing the specimen of Ga-rich plumbogummite to the attention of the lead author.

\section{References}

Anthony, J.W., Bideaux, R.A., Bladh, K.W. and Nichols, M.C. (2000) Handbook of Mineralogy, Volume IV, Arsenates, Phosphates, Vanadates. Mineral Publishing, Tucson, Arizona, USA.

Bajnóczi, B., Seres-Hartai, É. and Nagy, G. (2004) Phosphate-bearing minerals in the advanced argillic zones of high-sulphidation type ore deposits in the Carpatho-Pannonain region. Acta Mineralogica Petrographica, 45, 81-92.

Birch, W.D., Pring, A. and Gatehouse, B.M. (1992) Segnitite, $\mathrm{PbFe}_{3} \mathrm{H}\left(\mathrm{AsO}_{4}\right)_{2}(\mathrm{OH})_{6}$, a new mineral in the lusingite group, from Broken Hill, New South Wales. American Mineralogist, 77, 656-659.

Blount, A.M. (1974) The crystal structure of crandallite. American Mineralogist, 59, 41-47.

Brese, N. and O'Keeffe, M. (1991) Bond valence parameters for solids. Acta Crystallographica B, 47, 192-197.

Bruker (2005) SAINT, SADABS AND SHELXTL. Bruker AXS Inc. Madison, Wisconsin, USA

Cooper, M.A. and Hawthorne, F.C. (1994) The crystal structure of wherryite, $\mathrm{Pb}_{7} \mathrm{Cu}_{2}\left(\mathrm{SO}_{4}\right)_{4}\left(\mathrm{SiO}_{4}\right)_{2}(\mathrm{OH})_{2}$, a mixed sulphate-silicate with $\left[{ }^{[6]} \mathrm{M}\left(\mathrm{TO}_{4}\right)_{2} \mathrm{O}\right]$ chains. The Canadian Mineralogist, 32, 373-380.

Ferraris, G. and Ivaldi, G. (1984) X-OH and O-H $\cdots \mathrm{O}$ bond lengths in protonated oxoanions. Acta 
Crystallographica B, 40, 1-6.

Gebhard, G. (1999) Tsumeb II. A Unique Mineral Locality. GG Publishing, Grossenseifen, Germany, $328 \mathrm{pp}$.

Giraud, S., Wignacourt, J-P., Drache, M., Nowogrocki, G. and Steinfink, H. (1999) The stereochemical effect of $6 s^{2}$ lone-pair electrons: The crystal structure of a new lead bismuth oxyphosphate $\mathrm{Pb}_{4} \mathrm{BiO}_{4} \mathrm{PO}_{4}$. Journal of Solid State Chemistry, 142, 180-88.

Giusepetti, G. and Tadini, C. (1980) The crystal structure of osarizawaite. Neues Jahrbuch für Mineralogie Monatshefte, 401-407.

Giusepetti, G. and Tadini, C. (1987) Corkite $\mathrm{PbFe}_{3}\left(\mathrm{SO}_{4}\right)\left(\mathrm{PO}_{4}\right)(\mathrm{OH})_{6}$, its crystal structure and ordered arrangement of tetrahedral cations. Neues Jahrbuch für Mineralogie Monatshefte, 71-81.

Grey, I.E., Birch, W.D., Bougerol, C. and Mills, S.J. (2006) Unit-cell intergrowth of pyrochlore and hexagonal tungsten bronze structures in secondary tungsten minerals. Journal of Solid State Chemistry, 179, 3834-3843.

Grey, I.E., Mumme, W.G., Bordet, P. and Mills, S.J. (2008) A new crystal-chemical variation of the alunite-type structure in monoclinic $\mathrm{PbZn}_{0.5} \mathrm{Fe}_{3}$ $\left(\mathrm{AsO}_{4}\right)_{2}(\mathrm{OH})_{6}$, The Canadian Mineralogist, 46, $1355-1364$.

Grey, I.E., Mumme, W.G., Mills, S.J., Birch, W.D. and Wilson. N.C. (2009) The crystal chemical role of zinc in alunite-type minerals: structure refinements for pure and zincian kintoreite, American Mineralogist, 94, 676-683.

Hintze, C. (1933) Handbuch der Mineralogie. Vol. 1-4, Part 2, Walter de Gruyter and Co., Berlin. $1153-1159$.

Huminicki, D.M.C. and Hawthorne, F.C. (2002) The Crystal Chemistry of the Phosphate Minerals. Pp. 123-253 in: Phosphates - Geochemical, Geobiological, and Materials Importance (M.J. Kohn, J. Rakovan and J.M. Hughes, editors). Reviews in Mineralogy and Geochemistry, 48, Mineralogal Society of America, Chantilly, Virginia, USA.

Jambor, J.L. (1999) Nomenclature of the alunite supergroup. The Canadian Mineralogist, 37, $1323-1341$.

Jambor, J.L., Owens, D.R., Grice, J.D. and Feinglos, M.D. (1996) Gallobeudantite, $\mathrm{PbGa}_{3}\left[\left(\mathrm{AsO}_{4}\right)\right.$, $\left.\left(\mathrm{SO}_{4}\right)\right]_{2}(\mathrm{OH})_{6}$, a new mineral species from Tsumeb, Namibia, and associated new gallium analogues of the alunite-jarosite family. The Canadian Mineralogist, 34, 1305-1315.

Kharisun, Taylor, M.R., Bevan, D.J.M. and Pring, A. (1997a) The crystal structure of kintoreite, $\mathrm{PbFe}_{3}\left(\mathrm{PO}_{4}\right)_{2}\left(\mathrm{OH}, \mathrm{H}_{2} \mathrm{O}\right)_{6}$. Mineralogical Magazine, 61, 123-129.

Kharisun, Taylor, M.R., Bevan, D.J.M., Rae, A.D. and
Pring, A. (1997b) The crystal structure of mawbyite, $\mathrm{PbFe}_{2}\left(\mathrm{AsO}_{4}\right)_{2}(\mathrm{OH})_{2}$. Mineralogical Magazine, 61, 685-691.

Kolitsch, U., Bernhart, H.-J., Krause, W. and Blass, G. (2008) Pattersonite, $\mathrm{PbFe}_{3}\left(\mathrm{PO}_{4}\right)_{2}(\mathrm{OH})_{4}$ $\left[\left(\mathrm{H}_{2} \mathrm{O}\right)_{0.5}(\mathrm{OH})_{0.5}\right]_{2}$, a new supergene phosphate mineral: description and crystal structure. European Journal of Mineralogy, 20, 281-288.

Kolitsch, U., Tiekink, E.R.T., Slade, P.G., Taylor, M.R. and Pring, A. (1999a) Hinsdalite and plumbogummite, their atomic arrangements and disordered lead sites. European Journal of Mineralogy, 11, 513-520.

Kolitsch, U., Slade, P.G., Tiekink, E.R.T. and Pring, A. (1999b) The structure of antimonian dussertite and the role of antimony in oxysalt minerals. Mineralogical Magazine, 63, 17-26.

Krivovichev, S.V. and Brown, I.D. (2001) Are the compressive effects of encapsulation an artifact of the bond valence parameters? Zeitschrift für Kristallographie, 216, 245-247.

Laugier, J. and Bochu, B. (2004) Chekcell: Graphical powder indexing cell and space group assignment software, http://www.ccp14.ac.uk/tutorial//mgp/

Libowitzky, E. and Beran, A. (2004) IR spectroscopic characterisation of hydrous species in minerals. Pp. 227-279 in: Spectroscopic Methods in Mineralogy (A. Beran and E. Libowitzky, editors). EMU Notes in Mineralogy, 6. Eötvös University Press, Budapest.

Mills, S.J. (2007) The crystal chemistry and geochronology of minerals from Broken Hill. $\mathrm{PhD}$ Thesis, University of Melbourne, Australia, 249 pp.

Mills, S.J., Grey, I.E., Mumme, W.G., Miyawaki, R., Matsubara, S., Bordet, P., Birch, W.D. and Raudsepp, M. (2008) Kolitschite, a new arsenate mineral from Broken Hill, New South Wales, Australia. Australian Journal of Mineralogy, 14, $15-19$.

Moore, P.B. (1988) The joesmithite enigma: Note on the $6 s^{2} \mathrm{~Pb}^{2+}$ lone pair. American Mineralogist, 73, $843-844$.

Nakamoto, K., Margoshes, M. and Rundle, R.E. (1955) Stretching frequencies as a function of distances in hydrogen bonds. Journal of the American Chemical Society, 77, 6480-6486.

Scott, K.M. (1987) Solid solution in, and classification of, gossan-derived members of the alunite-jarosite family, northwest Queensland, Australia. American Mineralogist, 72, 178-187.

Sheldrick, G.M. (2008) A short history of SHELX. Acta Crystallographica A, 64, 112-122.

Slansky, E. (1977) Plumbogummite from Ivanhoe Mine, Northern Territory, Australia. Neues Jahrbuch für Mineralogie Monatshefte, 45-53.

Smith, D.G.W. and Nickel, E.H. (2007) A System of Codification for Unnamed Minerals: Report of the 
SubCommittee for Unnamed Minerals of the IMA

Commission on New Minerals, Nomenclature and
Classification. The Canadian Mineralogist, 45, 983-1055.

\section{Appendix}

A second crystal structure refinement was completed on another rhombohedral crystal of Ga-rich plumbogummite. The unit-cell parameters are: $a=7.1012(7) \AA, c=16.842(4) \AA$, $V=735.5(2) \AA^{3}$, with an $R_{1}=0.0296$ for 254 reflections. The refined $\mathrm{Pb} / \mathrm{Ca}$ and $\mathrm{Al} / \mathrm{Ga}$ ratios are: $\mathrm{Pb}_{0.85} \mathrm{Ca}_{0.15}$ and $\mathrm{Al}_{0.67} \mathrm{Ga}_{0.33}$. The average bond lengths are: $<(\mathrm{Al} / \mathrm{Ga})-\mathrm{O}>1.929 \AA,<\mathrm{P}-\mathrm{O}>$ $1.541 \AA$ and $<\mathrm{Pb} / \mathrm{Ca}-\mathrm{O}>2.797 \AA$, with $\mathrm{a}$ $\mathrm{O}(3)-\mathrm{H}(1) \ldots \mathrm{O}(1)$ distance of $1.052 \AA$. Atomic coordinates can be obtained from the corresponding author. 
